\title{
The WHO glove use pyramid: knowledge gaps among Belgian nurses
}

\author{
D De Wandel ${ }^{1,2^{*}}$, D Vogelaers ${ }^{3}$, S Blot $^{2,3}$ \\ From International Conference on Prevention \& Infection Control (ICPIC 2011) \\ Geneva, Switzerland. 29 June - 2 July 2011
}

\section{Introduction / objectives}

Appropriate glove use is a cornerstone in effective hand hygiene programs. Nurses' knowledge regarding appropriate glove use has only rarely been studied in Belgium.

\section{Methods}

We developed a questionnaire based on the WHO glove use pyramid. The pyramid was used as campaign material for the most recent national hand hygiene campaign (end of campaign May, 2009).Â The final questionnaire contained 36 glove use indications with four response alternatives: "no gloves indicated", "non-sterile gloves indicated", "sterile gloves indicated" and "I do not know". Demographic data such as sex, age, years of nursing experience and type of ward where respondents worked, were also collected. The questionnaire was completed during class by nurses following a Bachelorafter-Bachelor's course in the spring of 2009.

\section{Results}

The questionnaire was filled out by exactly 100 nurses (response 100\%). Maximum score was $94 \%$, minimum $22 \%$. The median total knowledge score (score $_{\mathrm{TOT}}$ ) was $81 \%$ (IQR 75-86). Some of the most striking gaps in knowledge were;

- $18 \%$ do not wear gloves when performing a venal puncture

- 37\% wear gloves when providing basic hygienic care and $18 \%$ wear no gloves when performing genital care (as a part of hygienic care)

- $29 \%$ will manipulate vascular catheters without gloves, $24 \%$ use sterile gloves

- 58\% prepare cytostatics with non-sterile gloves

The median score $_{\text {TOT }}$ for all acute care wards was $81 \%$ (IQR 78-85), respondents providing chronic or extramural

${ }^{1}$ Faculty of Health care, University College Ghent, Ghent, Belgium Full list of author information is available at the end of the article care scored 75\% (IQR 71-83). This difference was statistically significant (Mann whitney $\mathrm{U}$ test $\mathrm{P}<0.001$ ).

\section{Conclusion}

We identified several knowledge gaps concerning appropriate glove use in Belgian healthcare workers. Nurses working in acute care wards scored significantly higher compared to nurses working in other wards.

\section{Disclosure of interest}

None declared.

\section{Author details}

${ }^{1}$ Faculty of Health care, University College Ghent, Ghent, Belgium. ${ }^{2}$ Faculty of Medicine and Health Sciences, Ghent University, Ghent, Belgium.

${ }^{3}$ Department of General Internal Medicine and Infectious Diseases, Ghent University Hospital, Ghent, Belgium.

Published: 29 June 2011

\section{doi:10.1186/1753-6561-5-S6-P114}

Cite this article as: De Wandel et al:: The WHO glove use pyramid: knowledge gaps among Belgian nurses. BMC Proceedings 2011 5(Suppl 6):P114.

Submit your next manuscript to BioMed Central and take full advantage of:

- Convenient online submission

- Thorough peer review

- No space constraints or color figure charges

- Immediate publication on acceptance

- Inclusion in PubMed, CAS, Scopus and Google Scholar

- Research which is freely available for redistribution 